\title{
Effect of progesterone antagonist RU486 on uterine progesterone receptor mRNA expression, embryonic development and ovarian function during early pregnancy in pigs
}

\author{
D. Mathew' ${ }^{1}$ E. Sellner', C. Okamura', R. Geisert', L. Anderson ${ }^{2}$ and M. Lucy' \\ 'Division of Animal Science, University of Missouri, Columbia, USA; 'Department of Animal Science, \\ lowa State University, Ames, USA
}

Porcine peri-implantation development and maternal recognition of pregnancy is temporally associated with down-regulation of progesterone receptor (PGR) in the endometrial epithelium on days 10 to 12 (Geisert et al. 2006). One theory for down-regulation of uterine epithelial PGR is progesterone stimulates epithelial PGR to induce expression of RANKL [receptor activator for nuclear factor-kappa $B(N F-K B$ ) ligand or TNFSF11]. RANKL binds to its receptor, RANK (TNFRSF11A) to activate NF-KB. NF- $\mathrm{KB}$ and PGR are mutually antagonistic to one another. Activation of NF- $\mathrm{KB}$, therefore, may inhibit PGR expression and induce the increase in endometrial prostaglandinendoperoxide synthase 2 (PTGS2 or COX2) expression that occurs in the endometrium of cyclic and pregnant pigs on days 10 to 12 .

The PGR antagonist, RU486, could be used to determine if blocking PGR down-regulation in the uterine epithelium prevents RANKL expression and NF-אB activation. To test this hypothesis, gilts were inseminated at estrus $(\mathrm{d} 0)$ and assigned to one of three treatments: $\mathrm{RU} 486(400 \mathrm{mg} / \mathrm{d})$ on d 3,4 , and $5(\mathrm{~T} 1 ; \mathrm{n}=10) ; \mathrm{RU} 486$ on $\mathrm{d} 6$ and $7(\mathrm{~T} 2 ; \mathrm{n}=9)$; or control $(n=9)$. Blood was collected daily for plasma progesterone analysis, and the uterus and ovaries were harvested after slaughter on $\mathrm{d} 8$ or $\mathrm{d} 12$. Endometrial total RNA was isolated and analyzed with specific primers for RANKL, PTGS2, PGR isoform B (PGR-B) or the region common to $P G R$ isoforms $A$ and $B$ (PGR-AB) by real-time reverse transcriptase $P C R$ (RTPCR). NF-KB activation was measured by immunohistochemistry and scored objectively by three independent individuals.

Gilts treated with RU486 (T1 and T2) had heavier ovaries $(17.9,19.8$ and $16.1 \mathrm{~g}$ [SEM $=$ 1.1]; $T 1, T 2$ and control; $P<0.05)$, greater average follicular diameters $(5.6,4.9$ and 3.6 $\mathrm{mm}[\mathrm{SEM}=0.5] ; \mathrm{P}<0.01)$, a tendency for a greater number of corpora lutea $(16.8,15.0$ and 13.7 [SEM $=1.0] ; P<0.07$ ) and greater mid-cycle plasma progesterone concentration $(25.2,28.0$ and $20.6 \mathrm{ng} / \mathrm{mL} ; \mathrm{P}<0.05 ; \mathrm{d} 9$ to 11$)$. Uterine weight $(\mathrm{g})$ was reduced $(\mathrm{P}<$ $0.05)$ for $\mathrm{T} 1(608 \pm 46)$ compared with $\mathrm{T} 2(780 \pm 49)$ or control $(785 \pm 44)$.

Treatment of gilts with RU486 affected early embryonic development. The proportion of gilts with normal early embryonic development was lowest for gilts in $\mathrm{T} 1$ (chi-square $=11.2$; $P<0.01$; Table 1). There was a treatment effect $(P<0.01)$ on log-transformed RANKL mRNA expression (fold change relative to internal assay control) because compared with the control gilts, RANKL expression was greater in T1 (d 8 and d 12) and greater in T2 on d 12. Treatment affected both endometrial PGR-B $(P<0.001)$ and $P G R-A B(P<0.001)$ mRNA abundance. The PGR-B mRNA was more abundant in $T 1(9.1 \pm 1.0)$ compared with control $(3.1 \pm 1.0)$ with mRNA expression intermediate $(6.0 \pm 1.0)$ for $T 2$ pigs. Likewise, the 
PGR-AB mRNA was more abundant in $T 1(10.7 \pm 1.1)$ compared with control $(3.5 \pm 1.0)$ and the $P G R-A B$ for $T 2$ pigs was intermediate $(7.0 \pm 1.0)$. There was a day effect and a tendency for a treatment by day interaction $(P<0.06$; log-transformed data) for endometrial NF- $\kappa B$ activation. The amount of nuclear localization for activated NF-KB increased from $\mathrm{d} 8$ to $d$ 12 for $T 2$ and control pigs but remained relatively unchanged in T1 pigs (d 8 to 12). The pattern of PTGS2 mRNA expression was similar to that observed for NF- $\mathrm{kB}$ activation (day, $\mathrm{P}<0.001$; treatment by day, $\mathrm{P}<0.01$ ).

Table 1. Number and percent of gilts with normal embryonic development, relative mRNA amount in endometrium and luminal epithelium NF-kB activation $(0=$ cytoplasmic localization to $\mathbf{1 0}=$ nuclear localization) for pigs (d 0 = estrus) treated with RU486 on $\mathrm{d} 3,4$, and 5 (T1), RU486 on d 6 and 7 (T2), or untreated (control) with tissue collected on $\mathrm{d} 8$ or $\mathrm{d} 12$.

\begin{tabular}{|c|c|c|c|c|c|c|}
\hline & \multicolumn{3}{|c|}{ Day 8} & \multicolumn{3}{|c|}{ Day 12} \\
\hline & $\mathrm{T1}$ & $\mathrm{T} 2$ & Control & $T 1$ & $\mathrm{~T} 2$ & Control \\
\hline Normal development (\%) & $3 / 5(60)$ & $4 / 4(100)$ & $5 / 5(100)$ & $0 / 5(0)$ & $3 / 5(60)$ & $4 / 4(100)$ \\
\hline RANKL mRNA & $17.8 \pm 9.8$ & $3.7 \pm 10.9$ & $1.8 \pm 9.8$ & $26.6 \pm 10.9$ & $25.2 \pm 9.8$ & $2.8 \pm 10.9$ \\
\hline PGR-B mRNA & $11.0 \pm 1.3$ & $4.9 \pm 1.5$ & $1.9 \pm 1.3$ & $7.3 \pm 1.5$ & $6.9 \pm 1.3$ & $4.3 \pm 1.5$ \\
\hline PGR-AB mRNA & $10.4 \pm 1.3$ & $6.1 \pm 1.4$ & $2.8 \pm 1.3$ & $10.9 \pm 1.7$ & $8.0 \pm 1.4$ & $4.2 \pm 1.4$ \\
\hline$N F-k B$ activation & $2.4 \pm 0.6$ & $2.6 \pm 0.7$ & $2.2 \pm 0.6$ & $2.5 \pm 0.6$ & $4.0 \pm 0.6$ & $4.8 \pm 0.6$ \\
\hline PTGS2 mRNA & $1.0 \pm 0.6$ & $0.5 \pm 0.6$ & $0.3 \pm 0.6$ & $0.3 \pm 0.6$ & $4.4 \pm 0.6$ & $3.4 \pm 0.6$ \\
\hline
\end{tabular}

RU486 treatment stimulated ovarian follicular and luteal development perhaps by removing the inhibitory effect of progesterone on the ovary or hypothalamus. Early embryonic development was compromised for gilts treated with RU486 on d 3,4 and 5 (T1). Inhibition of progesterone action shortly after insemination, therefore, is incompatible with conceptus development and survival. There was a slight numeric reduction in the percentage of normal embryos on $\mathrm{d} 12$ for gilts treated with RU486 on $\mathrm{d} 6$ and $7(\mathrm{~T} 2)$. Blocking progesterone action with RU486 during early pregnancy increased PGR-B and PGR-AB mRNA expression on $\mathrm{d} 8$ and 12 . This supports the general concept that progesterone is responsible for PGR down-regulation in the uterine epithelium. Our results do not support the hypothesis that RANKL mediates NF-KB inhibition of PGR. Both RANKL and PGR expression were clearly elevated in $\mathrm{T} 1$ gilts on d 8 ; a time when activated $\mathrm{NF}$ - $\mathrm{\kappa B}$ was low. Endometrial RANKL expression does not appear to be responsible for NF-KB activation in the uterus and it is possible that another pathway for NF-KB activation such as Toll-fike receptor 4 could be involved. Activated $\mathrm{NF}-\mathrm{KB}$ was only detected on d 12 in treatments that were conducive to early conceptus development (T2 and control). Activation of NF-KB, therefore, was temporally associated with PGR down-regulation and the secretion of IL-1 $\beta$ by the elongating porcine conceptuses on $\mathrm{d} 12$ (Ross et al. 2003). The activation of NF-KB on $d 12$ coincided with greater PTCS2 expression; a response observed previously in the pig (Ashworth et al. 2005).

This project was supported by National Research Initiative Grant no. 2007-35203-17836 from the USDA Cooperative State Research, Education and Extension Service.

\section{References}

Ashworth MD, White FJ, Ross JW, Hu J, DeSilva U, Johnson GA \& Geisert RD 2005 Expression of porcine endometrial prostaglandin synthase during the estrous cycle, early pregnancy and following endocrine disruption of pregnancy. Biology of Reproduction 74 1007-1015.

Geisert RD, Ross JW, Ashworth MD, White Fl, Johnson CA \& DeSilva U 2006 Maternal recognition of pregnancy signal or endocrine disruptor: The two faces of oestrogen during establishment of pregnancy in the pig. In: Control of Pig Reproduction VII. pp 131-145 Eds R Kraeling \& C Ashworth. Nottingham University Press.

Ross JW, Malayer JR, Ritchey JW \& Geisert RD 2003 Involvement of the interleukin-lb system in porcine trophoblastic elongation and at the fetal-maternal interface during peri-implantation development. Biology of Reproduction 69 1251-1259. 